2 Standing Medical Advisory Committee: Sub-Group on Antimicrobial Resistance The path of least resistance. London: Department of Health, 1998 World Health Organization. The medical impact of the use of antimicrobials in food animals: Report of a WHO meeting, Berlin, Germany 13-17 October 1997. Geneva: WHO, 1997.

Livermore DM. Minimising antibiotic resistance. Lancet Infect Dis 2005;5:450-9.

Livermore DM. Can better prescribing turn the tide of resistance? Nat Rev Microbiol 2004;2:73-8.

Wise R. The relentless rise of resistance? J Antimicrob Chemother 2004;54: 306-10.

7 Reynolds R, Shackcloth J, Felmingham D, MacGowan A. Antimicrobial susceptibility of lower respiratory tract pathogens in Great Britain and susceptibility of lower respiratory tract pathogens in Great Britain and
Ireland 1999-2001 related to demographic and geographic factors: the BSAC respiratory resistance surveillance programme.J Antimicrob Chemother 2003;52:931-43.
8 Livermore DM, James D, Reacher M, Graham C, Nichols T, Stephens P, et al. Trends in fluoroquinolone (ciprofloxacin) resistance in enterobacteraceae from bacteremias, England and Wales, 1990-1999. Emerg Infect Dis $2002 ; 8: 473-8$.

Naimi TS, LeDell KH, Boxrud DJ, Groom AV, Steward CD, Johnson SK, et al. Epidemiology and clonality of community-acquired methicillinresistant Staphylococcus aureus in Minnesota, 1996-1998. Clin Infect Dis 2001;33:990-6.

10 Scott GM, Thomson R, Malone-Lee J, Ridgway GL. Cross-infection between animals and man: possible feline transmission of Staphylococcus aureus infection in humans? J Hosp Infect 1988;12:29-34.

11 Weese JS, Archambault M, Willey BM, Hearn P, Kreiswirth BN, Said-Salim B, et al. Methicillin-resistant Staphylococcus aureus in horses and horse personnel, 2000-2002. Emerg Infect Dis 2005;11:430-5.

12 Piddock LJ. Quinolone resistance and Campylobacter spp. J Antimicrob Chemother 1995;36:891-8.

\title{
What could Dr Finlay and Mr Herriot learn from each other?
}

\author{
Comparisons of human and animal diseases can benefit patients of all species
}

$\mathrm{T}$ The late 19th century brought recognition that normality and disease depended on similar mechanisms in humans and animals; leading scientists espoused the concept of "one medicine," calling it the medicine of the future. Comparative medicine largely failed to realise these expectations during the 20th century, becoming narrowly equated with induced rodent models of human disease. But veterinary and medical research have plenty to learn from each other.

Comparative medicine is the study of comparable diseases in different species; similarities and differences are both informative. Induced models are useful for identifying potential disease mechanisms, but spontaneous models come into their own with multifactorial diseases combining genetic, dietary, environmental, toxic, immune, and other factors-which are inherently difficult to model-and for the assessment of new treatments ahead of human trials, thereby bringing veterinary patients faster access to clinical innovations.

For many diseases-such as asthma, cystic fibrosis, and various cancers-rodent models are misleading, and therapeutic responses may differ profoundly from

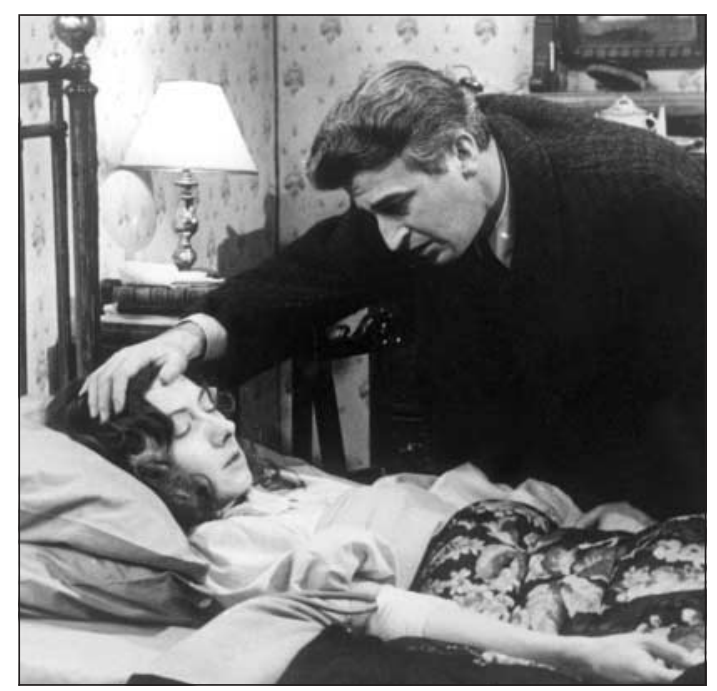

The iconic television general practitioner, Dr Finlay humans. ${ }^{1}$ The dog, for example, has several advantages over the mouse as a model of human disease. ${ }^{2}$ Many human tumours have canine counterparts, ${ }^{3}$ and, unlike in mice, telomerase reactivation may herald the onset of malignancy in dogs, potentially offering a therapeutic target. ${ }^{4}$

Our understanding of human hypertension is a good example of the power of comparative research. Knowledge of hypertension predated clinical blood pressure measurements; salt and renal disease were implicated 3000 years ago. The earliest blood pressure measurements, by Hales in 1733, mainly relied on dogs, as did the "Goldblatt model" of hypertension 100 years later and the research underlying Guyton's concept of "pressure natriuresis" as the long term regulator of arterial pressure. Genetic and salt sensitive hypertension and the renal role in blood pressure regulation and in renovascular and other forms of hypertension all emerged from studies in animals, notably dogs. Differences between breeds of dog in arterial pressure may yet offer insights into mechanisms or evolutionary origins of human essential hypertension: did the same genes confer biological advantage when human life was shorter and more active?

Lack of a comparative perspective often flaws research on hypertension through the use of exorbitant sodium intakes-such as rats given a diet comprising $8 \%$ salt, equivalent to a human consuming $6400 \mathrm{mmol} /$ day (a month's customary intake daily). Actually, mammalian requirement is probably below $0.6 \mathrm{mmol} / \mathrm{kg} / \mathrm{day}$, so the rat diet represents five months' nutritional requirement daily. ${ }^{5}$ The benefits of comparative research, exemplified by hypertension, include control over factors difficult to control in humans (such as diet and breeding), short generation time, and plentiful siblings (invaluable for studies of prenatal or perinatal factors in disease), and shorter lifespan and breed differences in lifespan (opportunities to study diseases of senescence and the biological basis of ageing).

Comparative medicine comes into its own in the field of genetics-genes shared between species far outnumber those that are unique. Alignment of 


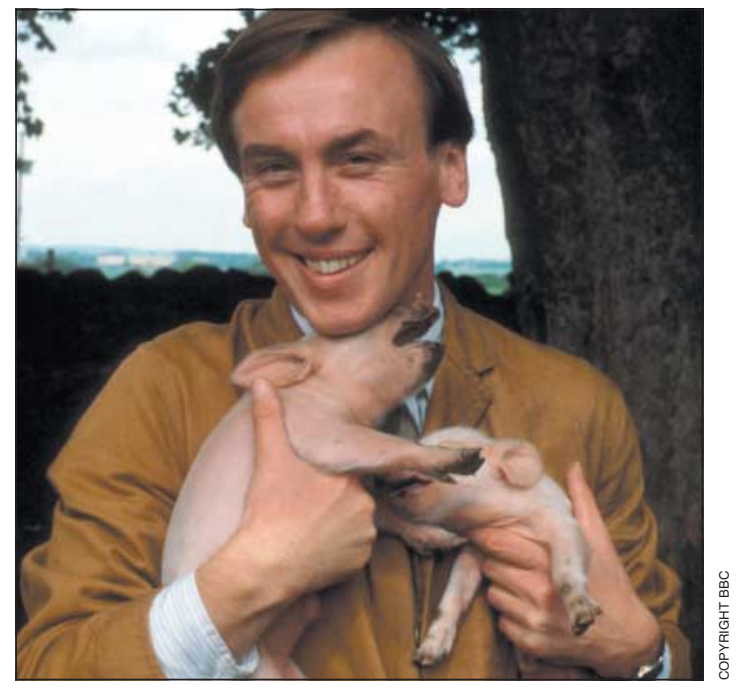

James Herriot-the popular vet from the television series All Creatures Great and Small

genome sequences between dogs, horses, cats, and humans is well advanced, ${ }^{67}$ with progress also in pigs, cattle, and sheep. Dogs combine exceptional phenotypic diversity, exemplified by breed differences in size and lifespan, with a relatively uniform genotype. Among some 370 canine genetic disorders, about half have exact human analogues. ${ }^{8}$ They generally resemble the human disease more closely than do rodent models, reflecting closer evolutionary kinship and DNA sequence identity. ${ }^{9}$ The National Human Genome Research Institute regards the canine genome as a key research priority. Molecular genetics adds new dimensions to comparative studiesidentification of novel disease genes, new disease models, new molecular targets for drugs, evaluation of gene therapy, and elucidation of genotypic variation in therapeutic responses.

Comparative medicine emerged from the realisation that humans and animals shared similar cellular structures and mechanisms and faced challenges from similar microorganisms. But disease models were just that; resemblances between diseases. Now molecular science can show identical receptors, mediators, and genes. This should not surprise us, unless we are creationists; we share a rich evolutionary legacy of genes, many involved in diseases. Comparative medicine is no longer the study of mere similarities but of the same disease in different species. We need parallel development of comparative clinical studies and research in molecular genetics. The Comparative Clinical Science Panel should provide the necessary strategic coherence to yield knowledge and reduce suffering, unfettered by species. ${ }^{10}$ In 1988 Stewart Cameron wrote: "Too little attention has been paid to comparison of human and spontaneous animal disease, either by veterinarians or physicians, and it is to be hoped that greater exchange of information can be organised in future." ${ }^{11}$ With the development of the Comparative Clinical Science Panel, this hope may now be fulfilled.

Bob Michell professor of comparative medicine

Barts and The London School of Medicine and Dentistry, John Vane Science Centre, London EC1M 6BQ

(bobmichell@hotmail.com)

Competing interests: None declared.

1 Coleman RA. Of mouse and man-what is the value of the mouse in predicting gene expression in humans? Drug Discov Today 2003;8:233-5.

2 Galibert F, Wilton AN, Chuat J. The canine model in medical genetics. In: Ruvinsky A, Sampson J, eds. The genetics of the dog. Wallingford: CABI, 2001:503-20.

3 Ostrander EA, Krugylack L. Unleashing the canine genome. Genome Research 2000;10:1271-4

4 Argyle DJ, Nasir L. Pathophysiology of cell regulation, cell death and cancer. In: Dunlop RH, Malbert C-H, eds. Veterinary pathophysiology. Oxford: Blackwell, 2004:25-78

5 Michell AR. The clinical biology of sodium. Oxford: Pergamon, 1995:105-54 6 Breen M, Switonski M, Binns MM. Cytogenetics and physical maps. In: Ruvinsky A, Sampson J, eds. The genetics of the dog. Wallingford: CABI, 2001:299-328.

7 Chowdhary BP, Raudsepp T, Kata SR, Goh G, Millon LV, Allan V, et al. The first-generation whole-genome radiation hybrid map in the horse identifies conserved segments in human and mouse genomes. Genome Res 2003;13:742-51.

8 Nicholas A. Genetics of morphological traits and inherited diseases. In: Ruvinsky A, Sampson J, eds. The genetics of the dog. Wallingford: CABI, 2001:87-116.

9 Van De Sluis B, Rothuizen J, Pearsen PI, Van Oost BA, Wijmenga C. Identification of a new copper metabolism gene by positional cloning in a purebred dog population. Hum Mol Genet 2002;11:165-73.

10 Michell AR. Comparative clinical science: the medicine of the future Veterinary Journal 2005;170;153-62.

11 Cameron JS. Glomerular disease in humans; comparative aspects. In: Michell AR, ed. Renal disease in dogs and cats; comparative and clinical aspects. Oxford: Blackwell Scientific, 1988:99-104.

\section{Human health and nature conservation}

\section{Ecotherapy could be beneficial, but we need more robust evidence}

$\mathrm{W}$ e call animals in their natural habitat wild, implying danger. Research that focuses on risk can foster a fearful attitude towards nature, disabling society's capacity for choice. ${ }^{1}$ These fearful views from contemporary anthropology contrast sharply with the biological, evolutionary, and ecological view of the influential American zoologist Edward Wilson. Wilson coined the concept of biophilia: "The connection that human beings subconsciously seek and need with the rest of life."' This view, emphasising connection with nature, builds on behavioural observations by Konrad Lorenz, a Nobel prize
The therapeutic implication of biophilia is ecotherapy: restoring health through contact with nature. ${ }^{4}$ British author Gregory Bateson's theoretical framework for improving health through conserving nature incorporated a "sense of unity of biosphere and humanity" that engenders connection, restoration, and respect for self and planet. ${ }^{5}$

The Society for Companion Animal Studies promotes pets for health, a topic discussed by McNicholas and colleagues in this issue. ${ }^{6}$ But extra benefits may come from the naturalness factor arising from connection with wildlife. Use of wildlife in some therapies is reported to improve quality of life. ${ }^{7}$ Smaller 